\title{
PHYSICO-CHEMICAL CHARACTERISTICS AND PRODUCTIVITY OF TOMATO PLANTS IN FUNCTION OF NITROGEN SOURCES AND DOSES
}

\author{
CARACTERÍSTICAS FÍSICO-QUÍMICAS E PRODUTIVIDADE DO TOMATEIRO EM \\ FUNÇÃO DE FONTES E DOSES DE NITROGENIO
}

\author{
Natália Silva ASSUNÇÃO ${ }^{1}$; Natalia Oliveira SILVA ${ }^{1}$; Flávio Lemes FERNANDES ${ }^{1}$; \\ Leonardo Angelo de AQUINO ${ }^{1}$; Maria Elisa de Sena FERNANDES ${ }^{{ }^{*}}$ \\ 1. Universidade Federal de Viçosa, Campus Rio Paranaíba. Programa de Pós-Graduação em Produção Vegetal, Rio Paranaíba, MG, \\ Brasil. mariasenafernandes@gmail.com
}

\begin{abstract}
The objective of this study was to evaluate the effect of nitrogen sources and rates on the physicochemical characteristics and yield of tomato plants. Forty hybrids were cultivated at 100 and $400 \mathrm{~kg} \mathrm{ha}^{-1}$ of $\mathrm{N}$, combined with four sources (urea, ammonium sulfate, ammonium nitrate and calcium), plus a treatment without $\mathrm{N}$ application in a randomized complete block design four replicates. Size, stem diameter, number of leaves, SPAD (Soil Plant Analysis Development), leaf nitrogen, number of fruits / plants, fruit firmness, bark thickness and average fruit size, ${ }^{\circ} \mathrm{BRIX}, \mathrm{pH}$, calcium, potassium and sodium in fruits. There was an increase in SPAD index, Brix and longitudinal diameter of fruits as a function of the $\mathrm{N}$ dose. The use of ammonium nitrate and calcium provided stronger fruits. Urea and ammonium nitrate provided the highest $\mathrm{pH}$ value in tomato fruits. The application of the $100 \mathrm{~kg}$ ha- 1 dose of $\mathrm{N}$ resulted in the highest potassium content in fruits. The highest productivity was obtained with the application of sources containing ammonium and the lowest in the control treatment. Sources and doses of nitrogen fertilizers influenced growth, productivity and parameters related to tomato quality.
\end{abstract}

KEYWORDS: Mineral nutrition. Yield. Solanum lycopersicum.

\section{INTRODUCTION}

The suitability of the nutrients supplied to tomatoes is one of the factors that directly influences their growth, and consequently their productivity and profitability for the producer (FERREIRA; FERREIRA; FONTES, 2010; MEHMOOD et al., 2012). Moreover, mineral nutrition is also important for some biochemical and physiological processes, such as the photosynthetic rate and photoassimilate translocation, and consequently influences the levels of some secondary plant compounds (FERREIRA et al., 2006). The cultivation of tomato plants presents high costs, mainly because of the high doses of fertilizers applied (SOUZA et al., 2010). As such, it is necessary to know the nutritional requirements of the tomato in order to obtain high fruit production and quality.

Among the relevant nutrients for tomato, nitrogen $(\mathrm{N})$ is highlighted because it contributes to increased plant growth, root dry matter, stems, leaves, fruits, plant height, number of leaves, leaf area, flowering, fruiting and productivity (FERREIRA; FERREIRA; FONTES, 2010; MEHMOOD et al., 2012; KUMAR et al., 2013), in addition to affecting the absorption of other nutrients, e.g. calcium and magnesium
(BORGOGNONE et al., 2013), influencing optimum tomato nutrition. Moreover, it affects characteristics that confer quality to fruits such as $\mathrm{pH}$, soluble solids concentration, titratable total acidity, contents of vitamin $\mathrm{C}$, nitrate, coloration and fresh weight.

Thus, adjusting the nitrogen fertilization is necessary to obtain high tomato productivity and maximize economic return (ARAUJO et al., 2007). Such an adjustment however is complicated because of the nitrification, leaching, volatilization and denitrification processes, which influence $\mathrm{N}$ availability in the soil. Other factors such as irrigation, pluviometric regime, fertilizer application mode, soil organic material quantity, predecessor crop, original $\mathrm{N}$ content in the soil, soil type and crop production potential in the specific tomato growing system make the $\mathrm{N}$ dose recommendation process difficult (ARAUJO et al., 2007).

Furthermore, the choice of nitrogen source is an essential factor for the cultivation of vegetables, because it directly influences both growth and production. The forms of $\mathrm{N}$, nitrate $\left(\mathrm{NO}_{3}{ }^{-}\right)$, ammonium $\left(\mathrm{NH}_{4}{ }^{+}\right)$and amide $\left(\mathrm{NH}_{2}\right)$, differ with regard to cost, leaching potential, soil acidification, volatilization and absorption by plants (MAROUELLI et al., 2014). Inorganic $\mathrm{N}$ in the form of $\mathrm{NO}_{3}{ }^{-}$or $\mathrm{NH}_{4}{ }^{+}$is preferentially absorbed by 
the roots depending on the species in question (GHANEM et al., 2011; MARTÍNEZ-ANDÚJAR et al., 2013), with the metabolic cost being lower for $\mathrm{NH}_{4}{ }^{+}$assimilation compared to $\mathrm{NO}_{3}^{-}$, since it needs to be reduced to then to be assimilated.

Ammoniated fertilizers, such as ammonium sulfate and urea, may in some cases present reduced efficiency when compared to other fertilizers, especially because of losses by ammonia volatilization (SCHIAVINATTI et al., 2011), depending on the growing conditions to which the culture is subjected. On the other hand, the application of nitric fertilizers, such as calcium nitrate, may be advantageous in crops that demand great quantities of calcium (PORTO, 2013). As such, we aimed to evaluate the effect of nitrogen sources and doses on the physico-chemical characteristics and productivity of tomato crops.

\section{MATERIAL AND METHODS}

The experiment was conducted in the experimental area of the Universidade Federal de Viçosa - Campus Rio Paranaíba, in Rio Paranaíba (Minas Gerais State, Brazil) $\left(19^{\circ} 12^{\prime} 53^{\prime \prime} \mathrm{S}\right.$ and $46^{\circ} 13^{\prime} 56^{\prime \prime} \mathrm{W}$, with altitude of $1140 \mathrm{~m}$ ) from April to August 2015, corresponding to the autumn planting. The soil used is classified as Red-Yellow Latosol of very clayey texture, with the following chemical attributes: $\mathrm{pH}($ water $)=5.3 ; \mathrm{P}($ Mehlich -1$)=4.6 \mathrm{mg}$ $\mathrm{dm}^{-3} ; \mathrm{S}=25 \mathrm{mg} \mathrm{dm}{ }^{-3} ; \mathrm{Ca}^{2+}, \mathrm{Mg}^{2+}, \mathrm{K}^{+}, \mathrm{H}+\mathrm{Al}$ and CTCpotential $=24 ; 5 ; 2.2 ; 61$ and $92.2 \mathrm{mmol}_{\mathrm{c}} \mathrm{dm}^{-3}$; organic material $=2.4 \mathrm{dag} \mathrm{kg}^{-1} ; \mathrm{B}, \mathrm{Cu}, \mathrm{Fe}, \mathrm{Mn}$ and $\mathrm{Zn}=0.81 ; 1.1 ; 49.0 ; 7.7$ and $3.5 \mathrm{mg} \mathrm{dm}^{-3}$.

The commercial hybrid Forty was used, with seedlings standardized with three fully expanded leaves, spaced $0.20 \mathrm{~m} \times 2.0 \mathrm{~m}$ apart and staked with tabs, alternating to form a "V", sloped at approximately $75^{\circ}$ with the soil surface. The tomato plants were grown with the apical bud removed above the $6^{\text {th }}$ infloresence, without pruning the fruits. The first bunch was removed, with the aim of redirecting photoassimilates to other organs of the plants (GUIMARÃES et al., 2009). In each bunch, fruits that were nonuniform, defective or with phytosanitary problems were removed.

The limestone dose applied to the total area was of $1.6 \mathrm{Mg} \mathrm{ha}^{-1}$ and the fertilizer was distributed manually in the experimental plots. The nitrogen fertilizer doses were 100 and $400 \mathrm{~kg} \mathrm{ha}^{-1}$ from four sources (urea, ammonium sulfate, ammonium nitrate and calcium nitrate). Such doses were calculated based on the total $\mathrm{N}$ content in the sources and distributed in six coatings according to the emission of the bunches. The total $\mathrm{K}_{2} \mathrm{O}$ dose $\left(530 \mathrm{~kg} \mathrm{ha}^{-1}\right)$ was distributed in fourteen coatings of $\mathrm{KCl}$, with the first three containing $30 \mathrm{~kg} \mathrm{ha}^{-1}$ of $\mathrm{K}_{2} \mathrm{O}$ and the rest of $40 \mathrm{~kg} \mathrm{ha}^{-1}$ of $\mathrm{K}_{2} \mathrm{O}$. The $\mathrm{P}_{2} \mathrm{O}_{5}$ dose was from $500 \mathrm{~kg} \mathrm{ha}^{-1}$ applied in the planting groove and two coatings of $50 \mathrm{~kg} \mathrm{ha}^{-1}$. In the planting groove $100 \mathrm{~kg} \mathrm{ha}^{-1}$ of $\mathrm{MgSO}_{4}, 20 \mathrm{~kg} \mathrm{ha}^{-1}$ of $\mathrm{ZnSO}_{4}, 6 \mathrm{~kg} \mathrm{ha}^{-1}$ of $\mathrm{H}_{3} \mathrm{BO}_{3}$ and $10 \mathrm{~kg} \mathrm{ha}^{-1}$ of $\mathrm{CuSO}_{4}$ were applied.

The treatments were distributed in a $(4 \times 2)$ +1 factorial scheme (four sources combined with two doses of $\mathrm{N}$, plus one treatment without the application of $\mathrm{N}$ ) in completely randomized blocks with four replicates. The experimental plots were 3 meters long with 15 plants in a single line, with this area being considered used by the seven central plants. The doses were applied on the planting line, throughout the 80 day crop cycle and irrigation was done with the drip system.

During the harvest, the leaves below the third bunch were removed with the objective of reducing the inoculum source of pests and disease, in addition to improving the incidence of light and aeration along the canopy. The other crop treatments such as weeding, thinning, mooring, irrigation and pest and disease management disease were done according to the recommendations for this crop (SILVA; VALE, 2007).

Plant height (PH), stem diameter (SD) and number of leaves emitted (NLE), were evaluated biweekly, totaling six evaluations during the cultivation period. The $\mathrm{PH}$ was measured with measuring tape, from the apex of the last fully expanded leaf to the base of the main stem. The SD was measured at the middle third of the stem with a digital caliper (Max Tools) and the NLE was obtained by counting the number of fully expanded leaves.

The SPAD (Soil Plant Analysis Development) index was measured with a portable chlorophyllmeter (SoilControl: CFL1030) on the terminal leaflet of the leaves opposite from the third and to the fourth bunch, at the time of emission. Measurements were done on four plants from each experimental unit.

Two index leaves were collected (opposite the third and the fourth bunches) in four plants from each experimental area. After collection, the impurities of a samples were removed using cotton soaked in distilled water and placed in an incubator with forced air ventilation at $70{ }^{\circ} \mathrm{C}$ for $72 \mathrm{~h}$. Afterward, samples were ground in a Wiley type mill equipped with $1.27 \mathrm{~mm}$ mesh and subjected to nitrogen analyses, following the methodology of Malavolta, Vitti and Oliveira (1997). 
The number of fruits per plant was determined by directly counting the total number of fruits on four plants per parcel. To evaluate firmness, two fruits were sampled from each parcel totaling eight fruits per treatment, washed with neutral detergent and sanitized with a $0.1 \%$ sodium hypochlorite solution. With the help of a penetrometer (TR: WA68, Italy, with an $8 \mathrm{~mm}$ diameter tip), these were perforated with a needle at two points per fruit. The resultant force required to perforate the fruit was expressed in $\mathrm{kg} \mathrm{cm}^{-2}$.

Peel thickness (PT) and average fruit size (FS) were evaluated in eight fruits per experimental unit. To evaluate PT, fruits were cut transversally. Both variables were measured with a digital caliper (Max Tools). For FS, the transversal and longitudinal diameters were measured in the central region of the fruits.

Four fruits were collected in each replicate, forming one sample per treatment, then crushed and passed through a mesh of $230 \mathrm{~mm}$. An aliquot was taken to determine soluble solids content, with values expressed in ${ }^{\circ}$ BRIX, measured on a portable digital refractometer (PAL-1), and $\mathrm{pH}$ of the pulp with a tabletop pHmeter (MS Tecnopon Instruments: mPA-210P) (AOAC, 1997), totaling three replicates for both variables.

The calcium $(\mathrm{Ca})$, potassium $(\mathrm{K})$ and sodium $(\mathrm{Na})$ contents were determined in the fruits. The fruits were washed in deionized water and dried in an incubator with forced air ventilation at $70{ }^{\circ} \mathrm{C}$ for $72 \mathrm{~h}$. Afterward, the samples were crushed in a Wiley type mill equipped with a $1.27 \mathrm{~mm}$ mesh and the nutrients were analyzed after mineralization by nitric-perchloric digestion. Thus, the $\mathrm{K}$ and $\mathrm{Na}$ were measured by flame emission photometry and $\mathrm{Ca}$ by atomic absorption spectrophotometry, following the methodology of Malavolta, Vitti and Oliveira (1997).

Fruits with orange-green coloration were harvested weekly and the fruits were weighed individually. Mean tomato productivity $\left(\mathrm{t} \mathrm{ha}^{-1}\right)$ was determined from the data on the tomato production tomato per plant, with mean fruit production extrapolated to an area of 25,000 plants, the equivalent of the quantity of plants found in one hectare with the spacing used in the experiment.

The obtained data were subjected to analysis of variance (ANOVA) and the means of the sources were compared by the Tukey test and the doses by the $\mathrm{F}$ test, both at $5 \%$. Additional comparisons of the control and the mean of the factorial were done by means of contrasts tested by the $t$ test. The program $\mathrm{R}$ was used for statistical analysis.

\section{RESULTS AND DISCUSSION}

When urea was applied, plant height increased as a function of the doses in the second evaluation. In a similar way, Mehmood et al. (2012) observed an increase in plant height as the dose of $\mathrm{N}$ applied increased. The lowest plant height, in the second evaluation, was obtained in the control treatment (Table 1). Aman and Rab (2013) and Mehmood et al. (2012) also reported that the treatment without $\mathrm{N}$ provided the lowest plant height. This variable is important for evaluating the responses of the plants to the crop treatments used, and consequently, their potential productivity and vigor (PORTO et al., 2014; KUMAR et al., 2013). This increase in plant growth as a function of the $\mathrm{N}$ doses is related to the formation of DNA and RNA as a function of the photosynthetic rate, resulting in increased cellular division and consequently plant growth (HAQUE et al., 2001).

With regard to the sources, in the second evaluation only, the calcium nitrate provided taller plants $(71.71 \mathrm{~cm})$ than the urea (Table 1). The $\mathrm{NO}_{3}{ }^{-}$, in addition to performing nutritional functions and cellular osmotic regulation, had a phytohormonal role, which is related to the cytokinin regulating and increasing cellular expansion and the quantity of solutes present in the interior of the cells (GWEYIONYANGO; NEUMANN; ROEMHELD, 2009). The other variables of the six vegetative evaluations done did not present significant differences.

The urea, sulfate and ammonium nitrate provided the lowest quantity of leaves emitted in the third evaluation (15.93), at the $100 \mathrm{~kg} \mathrm{ha}^{-1}$ dose (Table 1). This may be attributed to the fact that the toxicity caused by the $\mathrm{NH}_{4}^{+}$, which reduces plant growth, as well as negatively influencing the supply of cations for plant development, such as the calcium and magnesium (BORGOGNONE et al., 2013). Borgognone et al. (2013) observed that plant height, number of leaves, leaf area and dry biomass were reduced when $\mathrm{NH}_{4}{ }^{+}$was provided as the exclusive source of $\mathrm{N}$.

An SPAD index increase was observed with the $400 \mathrm{~kg} \mathrm{ha}^{-1}$ dose, compared to the $100 \mathrm{~kg} \mathrm{ha}^{-1}$ dose (Table 1). In general, this index increased when the dose increased, because of the high positive correlation between the nitrogen and chlorophyll content (ULISSI et al., 2011). Thus, the SPAD index may be used as a source for characterizing the nutritional state of $\mathrm{N}$ in tomato crops, in a rapid and non-destructive way (FERREIRA et al., 2006; MAROUELLI et al., 2014). 
Table 1. Mean plant height values $(\mathrm{cm})$ at the second and fourth evaluation, number of leaves emitted in the third evaluation, SPAD index, nitrogen content in the leaf index $\left(\mathrm{g} \mathrm{kg}^{-1}\right)$, number of fruits per plant and tomato productivity $\left(\mathrm{t} \mathrm{ha}^{-1}\right)$ as a function of the sources and doses of nitrogen.

\begin{tabular}{|c|c|c|c|c|c|c|c|c|c|}
\hline \multirow{2}{*}{$\begin{array}{c}\text { Dose } \\
\left(\mathrm{kg} \mathrm{ha}^{-1}\right)\end{array}$} & \multicolumn{4}{|c|}{ Source $^{T}$} & \multirow[t]{2}{*}{ Mean } & \multirow[t]{2}{*}{$\mathrm{F}_{\text {source }}$} & \multirow[t]{2}{*}{$\mathrm{F}_{\text {dose }}$} & \multirow[t]{2}{*}{$\mathrm{F}_{\text {interaction }}$} & \multirow{2}{*}{$\begin{array}{l}\mathrm{CV} \\
(\%)\end{array}$} \\
\hline & Urea & SA & NA & $\mathrm{NC}$ & & & & & \\
\hline \multicolumn{10}{|c|}{ Height $(\mathrm{cm}) 2^{\mathrm{a}}$ evaluation } \\
\hline 0 & $52.4 * *$ & & & & & & & & \\
\hline 100 & 57.1 & 63.7 & 65.6 & 71.7 & $64.6 \mathrm{a}$ & $4.28^{*}$ & 0.27 & $0.50^{\mathrm{ns}}$ & 11.5 \\
\hline 400 & 61.8 & 60.9 & 69.8 & 71.0 & $65.9 \mathrm{a}$ & & & & \\
\hline Mean & $59.4 \mathrm{~B}$ & $62.3 \mathrm{AB}$ & $67.7 \mathrm{AB}$ & $71.4 \mathrm{~A}$ & & & & & \\
\hline \multicolumn{10}{|c|}{ Height $(\mathrm{cm}) 4^{\mathrm{a}}$ evaluation } \\
\hline 0 & $104^{\mathrm{ns}}$ & & & & & & & & \\
\hline 100 & $114 \mathrm{Ab}$ & $122 \mathrm{Aa}$ & $124 \mathrm{Aa}$ & $124 \mathrm{Aa}$ & 121 & 0.87 & 2.65 & $3.39^{*}$ & 5.7 \\
\hline 400 & $130 \mathrm{Aa}$ & $124 \mathrm{Aa}$ & $129 \mathrm{Aa}$ & $118 \mathrm{Aa}$ & 125 & & & & \\
\hline Mean & 122 & 123 & 126 & 121 & & & & & \\
\hline \multicolumn{10}{|c|}{ Number of leaves emitted $3^{\mathrm{a}}$ evaluation } \\
\hline 0 & $14.1 * *$ & & & & & & & & \\
\hline 100 & $15.1 \mathrm{ABa}$ & $14.4 \mathrm{Ba}$ & $14.6 \mathrm{ABa}$ & 15.9 Aa & 15.0 & 2.14 & 1.93 & $1.53^{\dagger}$ & 4.8 \\
\hline 400 & $15.4 \mathrm{Aa}$ & $15.1 \mathrm{Aa}$ & $15.6 \mathrm{Aa}$ & 15.4 Аa & 15.4 & & & & \\
\hline Mean & 15.3 & 14.8 & 15.1 & 15.7 & & & & & \\
\hline \multicolumn{10}{|c|}{ SPAD } \\
\hline 0 & $56.50^{\mathrm{ns}}$ & & & & & & & & \\
\hline 100 & 56.8 & 55.9 & 56.8 & 55.2 & $56.2 \mathrm{~b}$ & 0.16 & $6.91 *$ & $0.94^{\mathrm{ns}}$ & 4.0 \\
\hline 400 & 58.5 & 59.7 & 57.0 & 59.0 & $58.3 \mathrm{a}$ & & & & \\
\hline Mean & $57.7 \mathrm{~A}$ & $57.3 \mathrm{~A}$ & $56.9 \mathrm{~A}$ & $57.1 \mathrm{~A}$ & & & & & \\
\hline \multicolumn{10}{|c|}{ Leaf nitrogen index $\left(\mathrm{g} \mathrm{kg}^{-\mathrm{T}}\right)$} \\
\hline 0 & $34.6^{\mathrm{ns}}$ & & & & & & & & \\
\hline 100 & 35.4 & 36.6 & 33.9 & 34.1 & $35.0 \mathrm{a}$ & $5.85 * *$ & 0.005 & $1.17^{\mathrm{ns}}$ & 4.0 \\
\hline 400 & 36.7 & 35.5 & 34.4 & 33.5 & $35.0 \mathrm{a}$ & & & & \\
\hline Mean & $36.0 \mathrm{~A}$ & $36.0 \mathrm{~A}$ & $34.1 \mathrm{AB}$ & $33.8 \mathrm{~B}$ & & & & & \\
\hline \multicolumn{10}{|c|}{ Number of fruits / plant } \\
\hline 0 & $23.0 * *$ & & & & & & & & \\
\hline 100 & $29.1 \mathrm{Aa}$ & $30.9 \mathrm{Aa}$ & $30.0 \mathrm{Aa}$ & $33.2 \mathrm{Aa}$ & 30.8 & 0.60 & 0.02 & $4.37^{*}$ & 10.5 \\
\hline 400 & $31.7 \mathrm{ABa}$ & $30.8 \mathrm{ABa}$ & $33.7 \mathrm{Aa}$ & $26.4 \mathrm{Bb}$ & 30.6 & & & & \\
\hline Mean & 30.4 & 30.9 & 31.84 & 29.8 & & & & & \\
\hline \multicolumn{10}{|c|}{ Productivity $\left(\mathrm{t} \mathrm{ha}^{-1}\right)$} \\
\hline 0 & $74.0 *$ & & & & & & & & \\
\hline 100 & $85.8 \mathrm{Aa}$ & $72.0 \mathrm{Bb}$ & $83.8 \mathrm{ABa}$ & $71.5 \mathrm{Ba}$ & 78.2 & $10.54 * *$ & $9.33^{* *}$ & $5.95^{* *}$ & 8.1 \\
\hline 400 & $94.8 \mathrm{ABa}$ & $96.6 \mathrm{Aa}$ & $82.5 \mathrm{BCa}$ & $70.0 \mathrm{Ca}$ & 86.0 & & & & \\
\hline Mean & 90.3 & 84.3 & 83.1 & 70.8 & & & & & \\
\hline
\end{tabular}

${ }^{1} \mathrm{SA}$ - ammonium sulfate; NA - ammonium nitrate; NC - calcium nitrate. Means of the sources and doses followed by a same capital letter on the line and lowercase letter in the column did not differ by the Tukey and F tests, both at 5\%. Mean of the control treatment followed by $* *$ or * indicate the significance of the contrast between this mean and the means of the other treatments followed by the $\mathrm{t}$ test at $1 \%$ and the $5 \%$. $\mathrm{F}_{\text {interaction }}$ value followed by $* *, *{ }^{\dagger}{ }^{\dagger}$ or ${ }^{\mathrm{ns}}$ indicate significance at $1 \%, 5 \%, 25 \%$ and not significant.

Fertilization with urea, sulfate and ammonium nitrate provided the highest mean values of $\mathrm{N}$ present in the leaf index (Table 1). No significant difference was observed in relation to doses however, unlike Marouelli et al. (2014), who observed a linear response of this variable in relation to the $\mathrm{N}$ doses. The results found in this research may be associated to the high fertility of the soil used.

For the number of fruits per plant, at the 100 $\mathrm{kg} \mathrm{ha}{ }^{-1}$ dose significant differences were not observed with respect to sources. However, for the
$400 \mathrm{~kg} \mathrm{ha}^{-1}$ dose the urea, sulfate and ammonium nitrate provided the highest quantity of fruits per plant. All treatments differed statistically from the control (Table 1). This result is in accordance with Mehmood et al. (2012) who evaluated the response of tomato crops to varying levels of $\mathrm{N}$ and noted that the lowest number of fruits per plant (21.82) was produced by the treatment without the application of N. This effect on the number of fruits should be mainly due to the hormonal balance on the aerated part of the plant, since the increased nitrogen supply also increases the synthesis of the 
Physico-chemical characteristics...

gibberellin hormone (GA) on the apex of the shoots and expanding leaves, consequently increasing the frutification (FELIPE; CASANOVA, 2000).

Regarding sources, the highest productivities for the $100 \mathrm{~kg} \mathrm{ha}^{-1}$ dose were obtained with the applications of urea $\left(85.2 \mathrm{t} \mathrm{ha}^{-1}\right.$ fruit $)$ and ammonium nitrate ( $83.8 \mathrm{t} \mathrm{ha}^{-1}$ fruit), with the same occurring at the $400 \mathrm{~kg} \mathrm{ha}^{-1}$ dose with the use of urea (94.2 $\left.\mathrm{t} \mathrm{ha}^{-1}\right)$ and ammonium sulfate $\left(96.2 \mathrm{tha}^{-1}\right)$ (Table 1). This response probably occurred due to the lower metabolic cost for $\mathrm{NH}_{4}^{+}$absorption (KANT et al., 2007), since the low temperatures during the period of tomato cultivation were reflected in lower photosynthetic rates and consequently lower energy production.

While the control differed from the mean of the other treatments, only the ammonium sulfate showed a difference in relation to the doses applied. This fact may be associated to the high $\mathrm{N}$ fertility in the soil used. Different results were found by Elia and Conversa (2012) with increased productivity in response to the application of increasing doses of $\mathrm{N}$. These different responses must be related to the crop and thus directly related to the root system of these plants and the absorption capacity of the available nutrients.

Different productivity results may be related to different crop responses in relation to the $\mathrm{N}$ application, as well as its availability, in addition to different soil types and crop patterns (MEHMOOD et al., 2012). It is well known however that the tomato yield is influenced by N (RAHMAN et al., 2007), by causing an increase in the absorption of other nutrients, as well as in the resistance of the plants to pests and diseases (AMAN; RAB, 2013).

The $400 \mathrm{~kg} \mathrm{ha}^{-1} \mathrm{~N}$ dose resulted in fruits with higher longitudinal diameters for the ammonium sulfate and calcium nitrate (Table 2). This characteristic is strongly influenced by levels of N (MEHMOOD et al., 2012), where the deficiency of this nutrient in the tomato crop may lead to a reduction in the number of fruits, fruit growth and fruit size (SAINJU; DRIS; SINGH, 2003). The transversal diameter did not present significant differences, differing from results found by Mehmood et al. (2012) that used doses of 0, 100, 150 and $200 \mathrm{~kg} \mathrm{ha}^{-1}$ of $\mathrm{N}$, with the highest and lowest transversal diameter obtained with the 200 and $0 \mathrm{~kg} \mathrm{ha}^{-1} \mathrm{~N}$ doses.

For peel thickness, there was a difference among the doses only with the ammonium sulfate,
ASSUNÇÃO, N. S. et al.

where the $400 \mathrm{~kg} \mathrm{ha}^{-1}$ dose provided fruits with lower thickness (Table 2). This result may indicate that the application of low doses of ammonium sulfate results in higher peel thickness, conferring quality to the fruits, since this is also a desirable parameter for tomato texture. These different responses of tomato peel thickness to the applied dose are important for the nutritional management of the crop, since the dose of nitrogen may be reduced during the fruiting phase and consequently the dose of another nutrient can be increased.

The ${ }^{\circ}$ Brix value was higher with the $400 \mathrm{~kg}$ $\mathrm{ha}^{-1} \mathrm{~N}$ application (Table 2), providing fruits with higher sugar content. The nitrogen plays an important role in biosynthesizing sugars in the leaves, which can be translocated to the fruits, increasing the concentration of soluble solids in the leaves (COLLA et al., 2001). This result was opposite that of Marouelli et al. (2014), who evaluated six $\mathrm{N}$ doses and did not observe a change in the ${ }^{\circ}$ Brix value, which remained at a mean value of 4.6, and to that of Bénard et al. (2009) where the soluble solids content increased as the $\mathrm{N}$ supply decreased. With regard to sources, the nitrate and ammonium sulfate presented the lowest ${ }^{\circ}$ Brix values (Table 2). Ammonium can negatively affect the stomatic conductance of the plant, directly interfering in the transpiration and photosynthesis and thus compromising growth (SILVA et al., 2010). The production of fruits with higher sugar content is important because it is a characteristic that directly influences consumer acceptability.

The increase in $\mathrm{N}$ dose decreased the mean $\mathrm{pH}$ value (Table 2). This result was opposite to the findings of Ferreira et al. (2006), who evaluated the application of increasing doses of $\mathrm{N}$ in the presence and absence of organic fertilizers to analyze tomato fruit quality, which did not undergo $\mathrm{pH}$ changes as a function of the doses. With regard to sources, the urea presented the highest $\mathrm{pH}$ value at the $400 \mathrm{~kg}$ $\mathrm{ha}^{-1}$ dose (Table 2). The same occurred when calcium nitrate, urea and ammonium sulfate were tested to evaluate the production and quality of fruits of tomato, among which the urea presented the highest value, not differing statistically from the ammonium sulfate (PORTO, 2013). That may be explained by the higher accumulation of mineral solutes in the fruit pulp, because of the presence of $\mathrm{NH}_{4}{ }^{+}$, which leads to the consumption of organic acids in $\mathrm{N}$ assimilation, favoring an increase in $\mathrm{pH}$ values (PORTO, 2013). 
Table 2. Average values of longitudinal diameter (mm), peel thickness (mm), ${ }^{\circ} \mathrm{Brix}, \mathrm{pH}$ and $\mathrm{Ca}, \mathrm{K}\left(\mathrm{g} \mathrm{kg}^{-1}\right), \mathrm{Na}$ $\left(\mathrm{mg} \mathrm{kg}^{-1}\right)$ content and tomato firmness $\left(\mathrm{kg} \mathrm{cm}^{-2}\right)$ as a function of the sources and doses of nitrogen.

\begin{tabular}{|c|c|c|c|c|c|c|c|c|c|}
\hline \multirow{2}{*}{$\begin{array}{c}\text { Dose } \\
\left(\mathrm{kg} \mathrm{ha}^{-1}\right)\end{array}$} & \multicolumn{4}{|c|}{ Source $^{1}$} & \multirow[t]{2}{*}{ Mean } & \multirow{2}{*}{$F_{\text {source }}$} & \multirow{2}{*}{$F_{\text {dose }}$} & \multirow{2}{*}{$\mathrm{F}_{\text {interaction }}$} & \multirow{2}{*}{$\begin{array}{l}\text { CV } \\
(\%)\end{array}$} \\
\hline & Urea & SA & NA & $\mathrm{NC}$ & & & & & \\
\hline & \multicolumn{9}{|c|}{ Longitudinal diameter (mm) } \\
\hline 0 & $61.1^{\mathrm{ns}}$ & & & & & & & & \\
\hline 100 & $61.4 \mathrm{Aa}$ & $59.5 \mathrm{ABb}$ & $60.9 \mathrm{ABa}$ & $58.9 \mathrm{Bb}$ & 61.1 & 1.97 & $7.06^{*}$ & $1.91^{\dagger}$ & 2.0 \\
\hline 400 & $61.3 \mathrm{Aa}$ & $61.6 \mathrm{Aa}$ & $61.2 \mathrm{Aa}$ & $61.1 \mathrm{Aa}$ & 61.3 & & & & \\
\hline \multirow[t]{2}{*}{ Mean } & 61.3 & 60.5 & 61.0 & 60.0 & & & & & \\
\hline & \multicolumn{9}{|c|}{ Peel thickness (mm) } \\
\hline 0 & $8.3^{\mathrm{ns}}$ & & & & & & & & \\
\hline 100 & 8.6 ABa & $9.6 \mathrm{Aa}$ & $8.8 \mathrm{ABa}$ & $7.8 \mathrm{Ba}$ & 8.7 & 2.81 & $22.7 * *$ & $4.72 * *$ & 9.3 \\
\hline 400 & $7.9 \mathrm{Aa}$ & $7.1 \mathrm{Ab}$ & $8.0 \mathrm{Aa}$ & $7.5 \mathrm{Aa}$ & 7.6 & & & & \\
\hline \multirow[t]{2}{*}{ Mean } & 8.3 & 8.4 & 8.4 & 7.6 & & & & & \\
\hline & \multicolumn{9}{|c|}{ Brix } \\
\hline 0 & $3.01^{\mathrm{ns}}$ & & & & & & & & \\
\hline 100 & 3.10 & 3.07 & 2.97 & 3.13 & $3.07 \mathrm{~b}$ & $11.39 * *$ & $5.92 *$ & $1.24^{\mathrm{ns}}$ & 2.4 \\
\hline 400 & 3.23 & 3.10 & 2.97 & 3.27 & $3.14 \mathrm{a}$ & & & & \\
\hline \multirow[t]{2}{*}{ Mean } & $3.17 \mathrm{~A}$ & $3.08 \mathrm{AB}$ & $2.97 \mathrm{~B}$ & $3.20 \mathrm{~A}$ & & & & & \\
\hline & \multicolumn{9}{|c|}{$\mathrm{pH}$} \\
\hline 0 & $4.43^{\mathrm{ns}}$ & & & & & & & & \\
\hline 100 & $4.46 \mathrm{Aa}$ & $4.42 \mathrm{Aa}$ & $4.40 \mathrm{Aa}$ & $4.40 \mathrm{Aa}$ & 4.42 & $8.48 * *$ & $10.68 * *$ & $1.55^{\dagger}$ & 0.7 \\
\hline 400 & $4.45 \mathrm{Aa}$ & $4.35 \mathrm{Bb}$ & $4.38 \mathrm{ABa}$ & $4.33 \mathrm{Bb}$ & 4.38 & & & & \\
\hline \multirow[t]{2}{*}{ Mean } & 4.46 & 4.38 & 4.39 & 4.37 & & & & & \\
\hline & \multicolumn{9}{|c|}{$\mathrm{Ca}\left(\mathrm{g} \mathrm{kg}^{-1}\right)$} \\
\hline 0 & $5.9^{\mathrm{ns}}$ & & & & & & & & \\
\hline 100 & 4.8 Aa & 4.9 Aa & $6.0 \mathrm{Aa}$ & $5.2 \mathrm{Aa}$ & 5.3 & $6.68 * *$ & 0.60 & $2.64^{\dagger}$ & 27.3 \\
\hline 400 & $3.8 \mathrm{Ca}$ & 4.2 $\mathrm{BCa}$ & $5.6 \mathrm{ABa}$ & $6.5 \mathrm{Aa}$ & 5.0 & & & & \\
\hline \multirow[t]{2}{*}{ Mean } & 4.3 & 4.5 & 5.8 & 5.8 & & & & & \\
\hline & \multicolumn{9}{|c|}{$\mathrm{K}\left(\mathrm{g} \mathrm{kg}^{-1}\right)$} \\
\hline 0 & $19.2 * *$ & & & & & & & & \\
\hline 100 & $18.3 \mathrm{Ba}$ & $20.3 \mathrm{Aa}$ & $20.5 \mathrm{Aa}$ & $16.9 \mathrm{Ca}$ & 19.0 & $187.27 * *$ & $46.57 * *$ & $7.92 * *$ & 1.5 \\
\hline 400 & $17.0 \mathrm{Cb}$ & $19.9 \mathrm{Aa}$ & $19.1 \mathrm{Bb}$ & $16.8 \mathrm{Ca}$ & 18.2 & & & & \\
\hline \multirow[t]{2}{*}{ Média } & 17.6 & 20.1 & 19.8 & 16.9 & & & & & \\
\hline & \multicolumn{9}{|c|}{$\mathrm{Na}\left(\mathrm{mg} \mathrm{kg}^{-1}\right)$} \\
\hline 0 & $330 * *$ & & & & & & & & \\
\hline 100 & $320 \mathrm{Bb}$ & $620 \mathrm{Aa}$ & $310 \mathrm{Ba}$ & $300 \mathrm{Bb}$ & 390 & $347.45^{* *}$ & $200.28 * *$ & $286.78 * *$ & 3.2 \\
\hline 400 & $350 \mathrm{ABa}$ & $340 \mathrm{Bb}$ & $240 \mathrm{Cb}$ & $370 \mathrm{Aa}$ & 320 & & & & \\
\hline \multirow[t]{2}{*}{ Mean } & 330 & 480 & 280 & 340 & & & & & \\
\hline & \multicolumn{9}{|c|}{ Firmness $\left(\mathrm{kg} \mathrm{cm}^{-2}\right)$} \\
\hline 0 & $5.9^{\mathrm{ns}}$ & & & & & & & & \\
\hline 100 & 4.8 Aa & 4.9 Aa & $6.0 \mathrm{Aa}$ & $5.2 \mathrm{Aa}$ & 5.3 & $6.68 * *$ & 0.60 & $2.64^{\dagger}$ & 27.3 \\
\hline 400 & $3.8 \mathrm{Ca}$ & 4.2 $\mathrm{BCa}$ & $5.6 \mathrm{ABa}$ & $6.5 \mathrm{Aa}$ & 5.0 & & & & \\
\hline Mean & 4.3 & 4.5 & 5.8 & 5.9 & & & & & \\
\hline
\end{tabular}

${ }^{1} \mathrm{SA}$ - ammonium sulfate; NA - ammonium nitrate; NC - calcium nitrate. Means of the sources and doses followed by a same capital letter on the line and lowercase letter in the column did not differ by the Tukey and F tests, both at 5\%. Mean of the control treatment followed by ** or * indicates the significance of the contrast between this mean and the means of the other treatments followed by the $\mathrm{t}$ test at $1 \%$ and at $5 \%$. $\mathrm{F}_{\text {interaction }}$ value followed by $* *,{ }^{*},{ }^{\dagger}$ or ${ }^{\text {ns }}$ indicate significance at $1 \%, 5 \%, 25 \%$ and not significant, respectively.

The highest $\mathrm{Ca}$ contents in the fruits at the $400 \mathrm{~kg} \mathrm{ha}^{-1}$ dose were found with the use of calcium nitrate, basically due to supply of this nutrient in the source, benefiting human consumption by the higher $\mathrm{Ca}$ intake, in addition to reducing specific diseases in the fruits, such as the incidence of black spots. The lowest levels however were found when using urea and ammonium sulfate, 3.78 and $4.17 \mathrm{~g} \mathrm{~kg}^{-1}$ (Table 2). Similar results were observed when the
$\mathrm{NH}_{4}{ }^{+}$was applied as the only source of $\mathrm{N}$, leading to a linear reduction in $\mathrm{Ca}$ content (BORGOGNONE et al., 2013), because this ionic form of $\mathrm{N}$ does not control cation absorption.

With regard to the $\mathrm{K}$ content, for the $100 \mathrm{~kg}$ $\mathrm{ha}^{-1}$ dose, both the sulfate and ammonium nitrate provided the highest contents, while at $400 \mathrm{~kg} \mathrm{ha}^{-1}$, only the ammonium sulfate stood out (Table 2). This allows the inference that the ammonium sulfate 
is a source that makes higher $\mathrm{K}$ content available in fruits for human consumption. For $\mathrm{Na}$ content, at the $100 \mathrm{~kg} \mathrm{ha}^{-1}$ dose the ammonium sulfate presented the highest contents, while calcium nitrate stood out when applied at a $400 \mathrm{~kg} \mathrm{ha}^{-1}$ dose (Table 2).

For fruit firmness the sources analyzed did not present significant differences when applied at the $100 \mathrm{~kg} \mathrm{ha}^{-1}$ dose. On the other hand, at the 400 $\mathrm{kg} \mathrm{ha}{ }^{-1}$ dose, the ammonium nitrate and calcium provided firmer fruits, due to the calcium availability by the last source (Table 2). This nutrient is related to the structure of the cell wall, conferring higher resistance, which is reflected in firmer fruits. While the urea and ammonium sulfate presented the lowest values, 3.8 and $4.2 \mathrm{~kg} \mathrm{~cm}^{-2}$ in relation to the calcium nitrate (Table 2). These results may be attributed to a competition between the $\mathrm{NH}_{4}{ }^{+}$and calcium by the absorption site, leading to a reduction in the absorption of this nutrient.

\section{CONCLUSIONS}

The $400 \mathrm{~kg} \mathrm{ha}^{-1} \mathrm{~N}$ dose provided an increase in the SPAD index, ${ }^{\circ}$ Brix and longitudinal diameter of the tomatoes.
The ammonium sulfate and the ammonium nitrate lead to lower ${ }^{\circ} \mathrm{Brix}$ values, while that the 100 $\mathrm{kg} \mathrm{ha}^{-1}$ dose and the use of urea and nitrate of ammonium leads to the highest values of $\mathrm{pH}$ in the fruits.

The sources that contain ammonium (urea, sulfate and ammonium nitrate) and the treatment control resulted in the highest and lowest values of productivity of tomato, respectively. In relation to the contents of the minerals, the $100 \mathrm{~kg} \mathrm{ha}^{-1}$ dose promotes the highest content of $\mathrm{K}$ in the fruits.

\section{ACKNOWLEDGMENTS}

To Conselho Nacional de Desenvolvimento Científico e Tecnológico (CNPq), Coordenação de Aperfeiçoamento de Pessoal de Nível Superior (CAPES) and Fundação de Amparo à Pesquisa do Estado de Minas Gerais (FAPEMIG).

RESUMO: Objetivou-se avaliar o efeito das fontes e doses de nitrogênio nas características físicoquímicas e produtividade do tomateiro. Foi cultivado o híbrido Forty com doses de 100 e $400 \mathrm{~kg} \mathrm{ha}^{-1}$ de N, combinadas com quatro fontes (ureia, sulfato de amônio, nitrato de amônio e de cálcio), mais um tratamento sem aplicação de $\mathrm{N}$ em delineamento em blocos casualizados com quatro repetições. Avaliou-se altura, diâmetro do caule, número de folhas, SPAD (Soil Plant Analysis Development), nitrogênio na folha, número de frutos/plantas, firmeza do fruto, espessura da casca e tamanho médio dos frutos, ${ }^{\circ} \mathrm{BRIX}, \mathrm{pH}$, cálcio, potássio e sódio nos frutos. Houve incremento do índice SPAD, ${ }^{\circ}$ Brix e diâmetro longitudinal dos frutos em função da dose de N. A utilização do nitrato de amônio e de cálcio proporcionou frutos mais firmes. A ureia e o nitrato de amônio propiciaram o maior valor de $\mathrm{pH}$ em frutos de tomate. A aplicação da dose de $100 \mathrm{~kg} \mathrm{ha}{ }^{-1} \mathrm{de} N$ acarretou o maior teor de potássio nos frutos. A maior produtividade foi obtida com a aplicação de fontes que continham amônio e a menor no tratamento controle. As fontes e as doses de fertilizantes nitrogenados influenciaram o crescimento, produtividade e os parâmetros relacionados à qualidade do tomate.

PALAVRAS-CHAVE: Nutrição mineral. Rendimento. Solanum lycopersicum.

\section{REFERENCES}

A.O.A.C. Official methods of analysis. 1997. Patrícia Cuniff, Arligton. p. 37-10, p. 42-2, p. 44-3, p. 45-16.

AMAN, S.; RAB, A. Response of tomato to nitrogen levels with or without humic acid. Sarhad Journal of Agriculture, v. 29, p. 181-186, 2013.

ARAUJO, C.; FONTES, P. C. R.; SEDIYAMA, C. S.; COELHO, M. B. Critérios para a determinação da dose de nitrogênio a ser aplicada no tomateiro em ambiente protegido. Horticultura Brasileira, v. 25, p. 327-332, 2007. https://doi: 10.1590/S0102-05362007000300003. 
BÉNARD, C.; GAUTIER, H.; BOURGAUD, F.; GRASSELLY, D.; NAVEZ, B.; CARIS-VAYRAT, C.; WEISS, M.; GÉNARD, M. Effect of low nitrogen supply on tomato (Solanum lycopersicum) fruit yield and quality with special emphasis on sugar, acids ascorbate, carotenoids and phenolic compounds. Journal of Agricultural and Food Chemistry, 2009, v. 57, p. 4112-4123. https://doi: 10.1021/jf8036374.

BORGOGNONE, D.; COLLA, G.; ROUPHAEL, Y.; CARDARELLI, M.; REA, E.; SCHWARZ, D. Effect of nitrogen form and nutrient solution $\mathrm{pH}$ on growth and mineral composition of self-grafted and grafted tomatoes. Scientia Horticulturae, v. 149, p. 61-69, 2013. https://doi: 10.1016/j.scienta.2012.02.012.

COLLA, G.; MITCHELL, J. P.; POUDEL, D. D.; SACCARDO, F.; HARTZ, T. K. Impacts of farming systems and soil characteristics on processing tomato fruit quality. Acta Horticulturae, v. 542, p. 333-341, 2001. https://doi.org/10.17660/ActaHortic.2001.542.43

ELIA, A.; CONVERSA, G. Agronomic and physioological responses of tomato crop to nitrogen input. European Journal of Agronomy, v. 40, p. 64-74, 2012. https://doi: 10.1016/j.eja.2012.02.001.

FELIPE, E. F.; CASANOVA, O. E. Fertilización con nitrogeno, fosforo y potasio en tomate (Lycopersicon esculentum Mill.) en suelos de vegas del Rio Guarico. Revista Unellez de Ciencia y Tecnologia, v. 17, p. 2144, 2000.

FERREIRA, M. M. M.; FERREIRA, G. B.; FONTES, P. C. R.; DANTAS, J. P. Qualidade do tomate em função de doses de nitrogênio e da adubação orgânica em duas estações. Horticultura Brasileira, v. 4, p. 141145, 2006. https://doi: 10.1590/S0102-05362006000200003.

FERREIRA, M. M. M.; FERREIRA, G. B.; FONTES, P. C. R. Eficiência da adubação nitrogenada do tomateiro em duas épocas de cultivo. Revista Ceres, v. 57, p. 263-273, 2010. https://doi: 10.1590/S0034$737 \mathrm{X} 2010000200019$.

GHANEM, M. E.; MÁRTINEZ-ANDÚJAR, C.; ALBACETE, A.; POSPISILOVÁ, H.; DODD, I. C.; PÉREZALFOCEA, F.; LUTTS, S. Nitrogen forms alters hormonal balance in salt-treated tomato (Solanum lycopersicum L.). Journal of Plant Growth Regulation, v. 30, p. 144-157, 2011. https://doi: 10.1007/s00344$010-9178-4$.

GUIMARÃES, M. A.; SILVA, D. J. H.; PETERNELLI, L. A.; FONTES, P. C. R. Distribuição de fotoassimilados em tomateiro com e sem a retirada do primeiro cacho. Bioscience Journal. v. 25, p. 83-92, 2009.

GWEYI-ONYANGO, J. P.; NEUMANN, G.; ROEMHELD, V. Effects of diferente forms of nitrogen on relative growth rate and growth components of tomato (Lycoperssicon esculentum Mill.). African Journal of Horticultural Science, v. 2, p. 43-55, 2009.

HAQUE, M. M.; HAMID, A.; BHUIYAN, N. I. Nutrient uptake and productivity as affected nitrogen and potassium application levels in maize/sweet potato inntercropping system. Korean Journal of Crop Science, v. 46, p. 1-5, 2001.

KANT, S.; KANT, P.; LIPS, H.; BARANK, S. Partial substitution of $\mathrm{NO}_{3}{ }^{-}$by $\mathrm{NH}_{4}{ }^{+}$fertilization increases ammonium assimilating enzyme activities and reduces the deleterious effects of salinity on the growth of barley. Journal of Plant Physiology, v. 164, p. 303-311, 2007. https://doi:10.1016/j.jplph.2005.12.011.

KUMAR, M.; MEENA, M. L.; KUMAR, S.; MAJI, S.; KUMAR, D. Effect of nitogen, phosphorus and potassium fertilizers on the growth, yield and quality of tomato var. Azad t-6. The Asian Journal of Horticulture, v. 8, p. 616-619, 2013.

MAlaVOlTA, E.; VITTI, G. C., OLIVEIRA, S. A. Avaliação do estado nutricional das plantas. Princípios e aplicações. Piracicaba, Brasil, 1997. 319p. 
MAROUELLI, W. A.; SOUZA, R. B.; BRAGA, M. B.; SILVA, W. L. C. Evaluation of sources, doses and application schedules of nitrogen on drip-irrigated tomato. Horticultura Brasileira, v. 32, p. 327-335, 2014. https://doi: 10.1590/S0102-05362014000300015.

MARTÍNEZ-ANDÚJAR, C.; GHANEM, M. E.; ALBACETE, A.; PÉREZ-ALFOCEA, F. Response to nitrate/ammonium nutrition of tomato (Solanum lycopersicum L.) plants overexpressing a prokaryotic $\mathrm{NH}_{4}{ }^{+}-$ dependente asparagine synthetase. Journal of Plant Physiology, v. 170, p. 676-687, 2013. https://doi: 10.1016/j.jplph.2012.12.011.

MEHMOOD, N.; AYUB, G.; ULLAH, I.; AHMAD, N.; NOOR, M.; KHAN, A.M.; AHMAD, S.; SAEED, A.; FARZANA. Response of tomato (Lycopersicon esculentum Mill.) cultivars to nitrogen levels. Pure and Applied Biology, v. 1, p. 63-67, 2012. https://doi: 10.19045/bspab.2012.13003.

PORTO, J. S. Fontes e doses de nitrogênio na produção e qualidade de tomate híbrido silvety. 2013. 97p. Dissertação (Mestrado em Agronomia) - Universidade Estadual do Sudoeste da Bahia, Vitória da Conquista, 2013.

PORTO, J. S.; AMORIM, Y. F.; REBOUÇAS, T. N. H.; LEMOS, O. L. J.; LUZ, M. Q.; COSTA, R. Q. Índice SPAD e crescimento do tomateiro em função de diferentes fontes e doses de nitrogênio. Scientia Plena, v. 10, p. 1-8, 2014.

RAHMAN, M. J.; MONDOL, A. T. M. A. I.; RAHMAN, M. N.; BEGUM, R. A.; ALAM, M. K. Effect of irrigation and nitrogen on tomato yield in the grey terrace soil of Bangladesh. Journal of Soil and Nature, v. 3, p. 1-4, 2007.

SAINJU, U. S.; DRIS, R.; SINGH, B. Mineral nutrition of tomato. Food Agriculure and Environment, v. 1, p. 176-183, 2003.

SCHIAVINATTI, A. F.; ANDREOTTI, M.; BENETT, C. G. S.; PARIZ, C. M.; LODO, B. N.; BUZETTI, S. Influência de fontes e modos de aplicação de nitrogênio nos componentes da produção e produtividade do milho irrigado no cerrado. Bragantia, v. 70, p. 925-930, 2011. https://doi: 10.1590/S000687052011000400027.

SILVA, P. C. C.; COUTO, J. L.; SANTOS, SANOS, A. R. Efeito dos íons amônio e nitrato no desenvolvimento do girassol em solução nutritiva. Revista da Faculdade de Zootecnia, Veterinária e Agronomia, Uruguaiana, v.17, p. 104-114, 2010.

SILVA, D. J.; VALE, F. X. R. Tomate - Tecnologia de produção. Suprema, Viçosa, Brasil. 2007. 356p.

SOUZA, J. A. R.; MOREIRA, D. A.; FERREIRA, P. A.; MATOS, A. T. Avaliação de frutos de tomate de mesa produzidos com efluente do tratamento primário da água residuária da suinocultura. Engenharia na Agricultura, v. 18, p. 198-207, 2010. https://doi: 10.13083/1414-3984.v18n03a02.

ULISSI, V.; ANTONUCCI, F.; BENINCASA, P.; FARNESELLI, M.; TOSTI, G.; GUIDUCCI, M.; TEI, F.; COSTA, C.; PALLOTTINO, F.; PARI, L.; MENESATI, P. Nitrogen concentration estimation in tomato leaves by VIS-NIR non-destructive spectroscopy. Sensors, v. 11, p. 6411-6424, 2011. doi: 10.3390/s110606411. 